\title{
A ELASTIC FIBER STAIN, ON ALDEHYDE-FUCHSIN TRICHROME STAIN
}

\section{K. SUGAI, K. FUKUSHI and K. KAWATSU}

Laboratory of Pathology, National Institute for Leprosy Research

(President: R. KOBAYASHI, Director: Y. YOSHIE)

Up to now, Weigert's resorcinfuchsin is used to stain elastic fibers histopathologically. Difficulty is present in the preparation of this staining solution. Gomori's aldehyde-fuchsin (1950) is a newer dye, derived from Schiff reagent, and applied to differential staining of $\beta$ cells of Langerhans' islets and hypophysis and elastic fibers. The preparation of this dye is very simple, and finest fibers are easily stained. By counter staining of trichrome, numerous tissue elements are discernible, the details of morphology of cells and stainabilities of protoplasma are rich and clear.

In this paper this excellent staining method is introduced.

\section{弾性線維染色法, 殊にアルデハイド

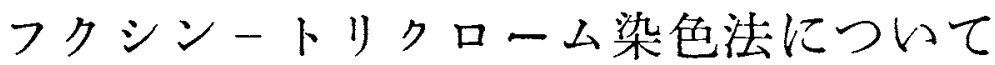 \\ 菅井健治・福士勝成・川津邦雄 \\ (昭和 31 年 10 月 11 日受稿)}

国立らい研究所・病理学研究害（所長：小林六造，研究部長：義江義㺘）

現在, 病理組織顕微鏡標本について弹性線維を矿べる 場合には，普通ワイゲルトの弾性線維染色液，即ちWEI GERT's Resorcinfuchsin'1 㚣用いているが，此の液は 出来不出来があり，共染が少く，而す䋐細な線維まで鮮 明以染め得る様な WEIGERT 染色液を作る事は中々困 難であり，仮们可成優秀なすのを作り上げたとしても蒸 登が早く, 為に濃度が变り易く液の保存には余程の注意 が必要となつて来る。

戦後アメリカの医学雑誌が入称出来る様になり, 弾性 線維染色として VERHOEFF's elastic-tissue stain ${ }^{213)}$ 法

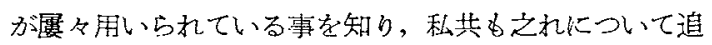
試を行つてみた。裳て病理学会等です此の染色法による 標本を散見したが，現在では殆んと見受けられない様で まる。私共は今回，此の染色法を記述するのが主な目的

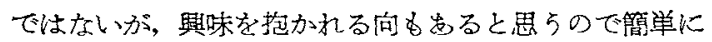
その方法を記して括と5。

始め心次の如き原液を調整して新く。ルゴール液（ヨ

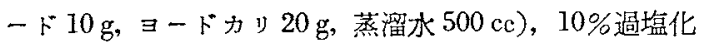
鉄一水溶液， $5 \%$ へマトキシリンーエタノール溶液等て
岁る。染色液を作るには $5 \%$ ママトキシリンーエタノー ル溶液 $60 \mathrm{cc}$ に, 24ccのルゴール液及び $24 \mathrm{cc} の 10 \%$ 過

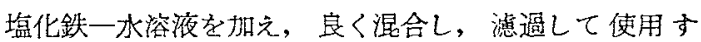
る。使用夜は新鮮なるのが良く，使用前に作る様にする 実施法としては，脱パラ後水洗して，

1. 染色液心入れる。15〜60分。

2. 水洗。

3. $2 \%$ 過塭化鉄一水溶液（10\%過塩化鉄一水溶液素 薄めて作れば良い）に入れて脱色，分別をする。数 秒。一寸水洗して顕微鏡下に染末り具合をチエック する。崔管壁の弾性線維が黒く浮き出て，周囲の焱 青灰色地加ら識别出来る。落し過ざの場合は再び染 色液心戻す。

4. 水洗。 5 分。

5. $95 \%$ ルコールに入れてヨードを除く。 5 分。

6. 水洗。 5 分。

7. 後染色。 van GIESON (酸性フクシンーピクリン 酸) 液に入れる。 5 分。

8. $95 \%$ ルュールで分別。 
9. 無水アルコール（或はアセトン）で脱水。キシロ ールで透徹。バルサムで封入。

結果。弾性線維及び核は黒色。結合織は赤色。筋組織 や原形翼は黄色炕夫々染まる。

此の染色法彷弾性線維や核が黑色に染まり，顕徽鏡写 真の為には效果的であるが，一般机標本が污く，たとえ van GIESON 液をかけても決して美㶾なすのとは言へな い㨀いが点る。

弾性線維の為の染色液が容易心調整山来, 而も貯蔵し ても比較的安定で，出来た標本が美簏で，長朝保存にた えるものですりたいと願らのは当然であるが，此の樣な

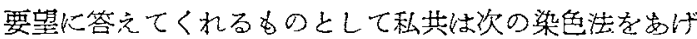
たい。

それは GOMORIによって提唱されたアルデハイドフ クシン4)法でする。此の場合後染色としてはトリクロー 厶法 ${ }^{57}$ が好ましい。以下染色液の作り方及び実施法汇就 いて記してみよら。

1.固定は目的とする被染色体が濃く出るので（murky shades), Zenker一フォルモールが望亲しいが，他 の如何なる固定液でも良い。

2.脱パラ。LUGOL 液て処理する。10３0 分。（晨承 を含玉ない国定液を使用した場合すルゴール処理を 行う樣化する。此の拠理によって,アルデハイドフ クシンと弹性線維との親和性が增し，染色時間老早 め，且染着が濃厚になるからでめる。）

$3.1 \sim 3 \%$ 重再硫酸水 $\left(\mathrm{NaHSO}_{3}\right)$ でョード除去す る。

4.アルデハイドフクシンで染色する。15〜30分。液が古 くなると時間がかかる。(場合に依っては所謂 over一 night する。慣れるまでは時々染色液から切片を取 出して，一寸アルコールで染色液を落し，顕徽鏡下 に血管壁弾性線維をみながら行い，適当のところで 染色を止める。過染せ好樣化する)。

アルデハイドフクシン液の作り方：濃 HCL $1 \mathrm{cc}$ と パラアルデハイト $1 \mathrm{cc}$ を 0.5\%塩基性フクシンーフ ルュール溶液 100 cd（この場合アルコールは60７0 \%エタノールを使用する）に加える。液は室温で約 24時間放置すると暗赤色より濃紫色となり，恰かも ゲンチアナ紫夜の様になる。ここで使用する。液は 室温だと約 1 ～2ケ月で効力が减ずるが，氷室に勋 之れば約 6 ケ月は充分使用出来る。

5. 60 70\%アルコール（原著には濃度は記載してな いるを入れた染色バットを2簓用意し，順次てれに 通して余分の染色液落す。（この時，㟋性線維は
紫色にくつきりと染め出される。菻ランゲルハンス 皂 $\beta$ 細胞や肥胖細胞顆粒も亦紫色汇染学る。）

6. WEIGERT 鉄へマトキシリンで核を染める。5〜 10 分。

7.水洗。10２0分。（核灶黒色をとる。鉄へマトキシ リンは後段トリクローム染色で使用する酸性液及び 分別液で落される為，やや過染気味飞染め上げる様 にする。だからと言つて核のデイテールが全く分ら なくなる程時間をかけるのを好京ない。

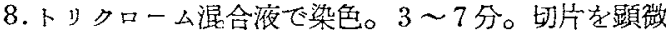
鏡下に観察し，適時染色を中止する。（筋肉や細胞 原形貿は赤く，結合織が緑色儿，赤血球は橙色儿染 まる。)

トリクローム混合液の作り方：先つ头醋酸 $3 \mathrm{cc}$ を $50 \%$ × ール $300 \mathrm{cck}$ 加完，との酸性丁ルコール を $50 \mathrm{cc}$ 宛 4 つのビーカー, 又は三角コルベン稄 し, 第一の容器に酸性フクシン $0.5 \mathrm{~g}$ 及びポンソー $2 \mathrm{R} 1.0 \mathrm{~g}$ 老溶かす。第二の容器にライト緑 SF（yellowish) $0.45 \mathrm{~g}$ ，第三の容器にオレンヂ G 0.75 $\mathrm{g}$ 及び燐タングステン酸 $1.5 \mathrm{~g}$ を第四の容器心燐七 リブデン酸 $1.5 \mathrm{~g}$ を夫々溶かす。橉タングステン酸 は容易に溶解するが，燐モりブデン酸は加温して溶 かす様行る。支等の溶液を別の容器に集め，余つ た酸性アルコールを追加してよく混合し澺紙てと 寸。

$9.0 .2 \%$ 醋酸一水溶液で短時間分別。スライドを持つ て4〜5回パットを往復さやる程度で良い。

10. $95 \%$ ，100\%アルコールを通す。キシロール透徹。 バサム卦入。

結果：核は黑色。弾性線維・肥胖細胞 (mast cells) ・ 胃粘膜の主細胞 (chief cells)・满ランゲルハンス島 $\beta$ 細 胞・脳下垂体前葉の $\beta$ 細胞・粘膜上皮皮婜縁・粘液は紫 色。結合織線維は稍青味を带びた緑色。カルシウムは深 紅色。ヒヤリンは淡青色。コロイドは橙色か淡紅色。タ ラチンは橙赤色。赤血球は橙色。へモジデリン,リポフ スチンは橙緑色。前立腺小体は青緑色，その或物住中心 が撜褐色に染るる。神経膠質は黄赤色。軸索はピンク。 内及び外神経鞘は緑色化夫々染まる。

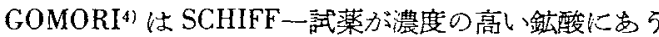
と，強く脱色を行なはなければ愳基性フタシン自身は或 るアルデハイドと結合して漸紫色を呈する事に注目し， 更に formaldehyde, paraldehyde (trimer acetaldehyde), propionaldehyde, $\mathrm{n}$-butyraldehyde, benzaldehyde, dimethylamino-p-benzaldehyde, vanillin 及び furfural 等の 
色々のアルデハイドを塩基性フクシンの強酸溶液に加え てて, 此の中の paraldehyde, propionaldehyde 及び butyraldehyde $か ゙$ 著明に変色 $L$, 就中 paraldehyde: $\left(\mathrm{C}_{2}\right.$ $\left.\mathrm{H}_{4} \mathrm{O}\right)_{3}$ が弾性線維を最す強く染色する事を知つた。 aldehyde-fuchsin は此の様にして “新しい色素”として認識 される様になつたのである。

SCHIFF一試莧は確か心用いる固定法・分別法及び対 染色法等心十分の注意を问けないと可成多角的な染色性 そ示す為にその意義が不明確になる様に感しられる。此 の多角的な一面を取り上げたのが GOMORI のアルデ イドフクシンに他ならないが，SCHIFF の試薬によつて 弹性線維か紫色に盖色する事は GOMORI 以前に FEULGEN \& VOIT (1924) 等心よつて既に発見されて打り， フエニールヒドラジン, 或いは重重硫酸ソーダで処理す ると，反応性㓌性になる事も認められている。

GOMORI $460 \%$ はュールに溶かした SCHIFF一 試薬にパラアルテハイドを加えると日細胞だけを強く染 め，弾性線維を染め出さず，又古い染色液では弾性線維 のみが染まり， $\beta$ 細胞は染まらなくなる(私共の経験で 讴, 水空内保存約 6 ケ月の液が此の様な傾向を示した) 事を奇異な現象として述べ，此の染色法がオルセインや レゾルシンフクシン等と必ずしる全く同一の染色性を持 つものではないらしいと結九でいる。

アルデハイドフクシンによる被染色体に関しては，ア ルデハイド化合物が問題でめるととは推定されるが，弾 性線維にプラズマロジェーンが強く吸着した FEULGEN \& VOIT' 1924) 為之b，脂肪体の代謝によつて生した 末知物筫が眀着した（VERNE，1928-9）為とも考入ら れているが，事㶳は脂肪体である証明もなく，推定の根

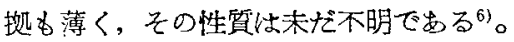

後染色のトリクローム法についてては既に原田”によつ て GOLDNER一变法が本誌上に記載されてをり，その 染色液の作り方及び染色法については省略するが，此の 染色法が瀬絴胞学筧察する場合 LILLIE の allochrome 法と其に優秀な方法でする事は原田 ${ }^{8}$ によつて速べられ てをり，此の点私共も同感である。

MASSON $^{91}$ のトリクロームはその後 GOLDNER ${ }^{10)}$ に 上つて変法が, 次いで POLLAK ${ }^{5}$ によつて混合液によ

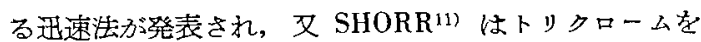
登沫標本に応用している。併し GOMORI ${ }^{12)}$ は種々の acid triphenylmethane 禾色素と sulfonated red azo-及 びdiazo-系色素を0.5〜1.0\%燐タングテンン酸或は燐モ リブテン酸及び $1.0 \%$ 醋酸混合液中に種々の割合で組合 わ就色謂のニニアンスを調ベ，例へば燐タングステン
酸は赤味を，燐モリブデン酸は緑味を増す傾向があり， 混合液はアルコールを抈えると赤味を抑えて, 緑味を出 し，短時闆の染色では赤味を带びるものも，長時間では 緑味が強調され，BOUIN 液で $56 \sim 60^{\circ} \mathrm{C} ., 2 \sim 5$ 分処理 (bouinize) すると赤味が增し，勆線維や上皮の細胞間 橋の線維が良く出る様になり，0.2\%醋酸で分別する場 合は急激な変色を起さずに更にテりヶートの色調をもた らすが，流水では赤味加落らるといっている。

今国後染色のトリタローム法としては POLLAK よる迅速法を採用したが，之は簡便で各といふ点を心 脚け大からであるが，一方 GOLDNER ${ }^{10)}$ 変洼位染色上 のステップが多いけわどぬ，その都度コントロール出来 る点で捻てが大いものが宏ると思5。

又 GOMORI ${ }^{12}$ の迅速法の為の湿合液は $0.6 \mathrm{~g}$ の chromotrope $2 \mathrm{R}, 0.3 \mathrm{~g} \sigma$ fast green $\mathrm{CFC}$ 或仗 light green $\mathrm{SF}, 0.6-0.7 \mathrm{~g}$ の燐 タングステン酸及び $1 \mathrm{cc} の$ 水醰酸を $100 \mathrm{cc}$ の蒸溜水に溶かして作る（実施法は POLLAK ${ }^{5}$ の 迅速法と変らない)。

此の处方から伺われる様心 orange-G の如き黄色色素 を用いていないるその理由としては orange-G によつて 赤色色素がすつかり置换されてしまい，同時化此等の色 調を現出し得ないからだと述べている。併し私共はやは り orange-G を使用する事心よつて可成デリろートな色 調の段階が把握出来る様に䍐つているので POLLAK ${ }^{5)}$ 法をとり岕げて怙いた。

注意としては多くの染色腹を同一切片に使用する為， 美蟫な標本でする為火は少くとも5ミクロンを超えない 厚さの切片である事が望木れるのは勿論である。

分塩基性フクシンは国産化学菜品研究所製の fuchsine red を使用した。之は basic fuchsine, brilliant fuchsine, rubine, magenta red 等と呼ばれるものでまつて, Fuchsin pulver (MERCK) は此のアルデハイドフクシン法には 不適で步る事を附け加えて括く。

以上現在余り用いられていない弾性線維染色としての アルデハイトフクシン法及びその後染色としてのトリタ モーム洗について記述した。

（本法の実施に際して，いろいろと御指示下さつた東 大病理・斎藤守助教授亚儿文献を扎世話下さつた伝染病 研究所病理・青山友三学士に心からの謝意を表明する次 第である。)

\section{主要参考文献}

1. 緒方知三郎編：病理組織㩆锁鏡標本の作り方手任 ぞき，9版，p. 152〜156, 南出堂（昭和 30） 
2. VERHOEFF, F. H. : Verhoeff's elastie-tissue stain J. A. M. A., $50: 876 \sim 877$ (1908)

3. McCLUNG, R. J. : McClung's handbook of microscopical technique, for workers in animal and plant tissues, 3 rd ed., p. 261-262, Paul B. Hoeber, Inc. (1950)

4. GOMORI, G.: Aldehyde-fuchsin: A new stain for elastic tissue, Am, J. Clin. Path., 20: 665 666 (1950)

5. POLLAK, O.: A rapid tricorome stain, Arch. Path., $38: 294$ (1944)

6. LISON,L.: Histochimie et cytochimie animales, pricipes et méthodes, Gauthièr-Villars (1953) 今泉正訳 : 組織化学および細胞化学, 理論と方法, $p 347 \sim 348$, 白水社 (1954)

7. 原田澄：瘦組織の染色につい（其の1），レプ
5, 24: 118 122(昭和 30)

8. 原田澄: 稆維化学的研究 (等 1 報), とくに 瀨細胞の形成について，レプラ，24: 277〜282 (昭和 30)

9. MASSON, P.: Trichrome stainings and their preliminary technique, J. Tech. Methods, 12: 75 90 (1929)

10. GOLDNER, J.: A modification of the Masson trichrome technique for routine laboratory purpose, Am. J.Path., 14: 237 243 (1938)

11. SHORR, E. : A new technic for staining vaginal smears, III. A single differential stain, Science, $94: 545 \sim 546$ (1941)

12. GOMORI, G.: A rapid one-step trichrome stain, Am. J. Path., 20: 661 664 (1950) 